\title{
Evaluation of Quality in Computer Games
}

\author{
KJeTIL SANDVIK
}

\begin{abstract}
Computer games play an important role in the cultural daily life of children, teenagers and adults. This has led to arguments both in the EU and the Nordic countries that computer games should be included in the culture political strategies for financial funding as well as the development of talents for the game industry. Still this has yet to result in culture political efforts and progressive strategies on a larger scale. On the contrary the political initiatives tend to result in restrictions more than efforts being made to encourage and develop the game industry. This article draws a picture of the current culture political situation and criticizes the media skeptical debate for making a poor starting point for formulating a progressive political strategy. It would be more fruitful to have a closer look at the specific characteristics of computer games and how computer games are being played and the role they are playing in the social life of different groups of player. The article outlines ananalytical apparatus for evaluation of quality in computer games.
\end{abstract}

Key Words: computer games, cultural politics, game culture, game quality, game's damaging effects, game addiction

\section{Introduction}

You can not judge a book by its cover. You can not evaluate the quality of computer games just by looking at its content. You need to examine how this content is structured in an interactive way which enables the computer player to engage in as well as to influence this content and the way it is played out. Computer games engage in dialogues with their players and also with the context of the gameplay situation. Having a concept of quality and an apparatus for performing this kind of evaluation is crucial when politicians design strategies for funding game development in order to encourage new game concepts and high quality content.

During the last decade or so computer games have grown into becoming a major player within the field of cultural production and consumption. Globally the game industry is larger than the film industry and consume of computer games exceeds that of both movies and television. Thus computer games have come to play an important role in the cultural daily life of both children, teenagers and adults. This has led to arguments in the Nordic countries that computer games should be included in the culture political strategies both in the sense of creating possibilities for financial funding of computer 
game development especially when it comes to computer games for the European and Nordic markets as a counterweight to the massive overflow of games produced in the US and Japan and in the sense of developing talents for the game industry. Still this has yet to result in concrete culture political efforts and progressive strategies on a larger scale. On the contrary some of the political initiatives concerning computer games tend to result in restrictions rather than efforts being made to encourage and develop the game industry in the Nordic countries. To some degree political debates appear to deal mainly with the questions of whether games are damaging and addictive and are fueled by media skepticism and prejudice towards new media such as computer games even when the debate evolve around the possibilities for funding computer game development.

Taking the current culture political situation as its point of departure this article criticizes the media skeptical debate for being both founded on very little scientific evidence and making a poor starting point for formulating a progressive politics for computer game development as well as consume. The article proposes that it would be more fruitful to try to look deeper into the specific characteristics of computer games and into how computer games are being played and the role they play in the social life of e.g. children. Using a model for evaluation of quality in performance art and a set of concepts describing the nature of computer games, the article tries to transgress the media skeptical and prejudiced debate led by many politicians, organizations and the news media and seeks to formulate an understanding of computer games' major characteristic. This may serve as a useful point of departure for a culture political strategy in the Nordic countries which aims at creating a Nordic market for developing computer games with high quality by strengthening the local game industry and making its potential grow by means of funding, creating incitements for venturing companies to invest and by means of education and research within the field of computer games.

My point will be that the main characteristics of computer games as a work of art as well as a type of communication are that computer games' interactive plot-structure and fictional worlds facilitates new ways for the recipient to deal with the work or media message. There is no longer an interpretation at work distanced from the work or media message itself but an interpretation, which becomes an active participator and agent in the enunciation of the work. The work is so to speak engaging in a dialogue with its recipient. The work is thus open in the way described by Umberto Eco (1989): The work confronts its recipient as unfinished and is susceptible to influence, and the recipient's interpretations and interaction with the work is what completes it.

\section{Developing 'Hot Spots'}

There are several reasons why developing an analytical apparatus for evaluating the quality of computer games should be of interest not only in a Nordic context but in a global perspective. The game industry has not only grown to be one of the larger producers of cultural products, it has also matured in to a state where the marked to a high degree is controlled by large publishers (such as Electronic Arts) and to a greater extent by the game console producers (such as Sony, Nintedo and Microsoft) who play the role as gatekeepers controlling the content of new games distributed to the market and to the consoles (PS2, PSP, Xbox 360, GameCube, GameBoy, DS and so on). This is a quite natural situation:

Seen from a marketing viewpoint, there is little that is odious in this procedure, as the companies invest huge sums in placing these sophisticated, interactive 
technologies in the home of the user. But seen from a content and user-oriented viewpoint, this highly centralized, top-down managed system inevitably leads to commercial interests being put above considerations of quality, multiplicity and innovation. (Fonnesbech 2002: 15)

So what we have is a global game market dominated by few but successful game concepts spawning both new games and sequels to old ones (with $53 \%$ of the titles released in 2003 falling into the action game category: $1^{\text {st }}$ and $3^{\text {rd }}$ person shooters, combat games, war games, racecar games and so on). Thus we got a situation where very little innovation is happening on a global scale as far as inventing new game concepts and content is concerned. This situation can also be explained by the fact that computer games (especially console games) are very expensive to produce and that the commercial game marked is extremely tough with a high degree of competition and short sales periods (even a blockbuster production can be sold at full prize for only a few months), which means that even well-established developers and publishers may risk bankruptcy if a game flops (as was the case with British publishing company Eidos who experienced a takeover by another British game company SCI in 2005 because the company (despite their commercial game successes like the Tomb Raider and Hitman series) had experienced that several of their titles failed to sell on the American market). So what is needed is to facilitate new game producing environments and conditions other than the ones found on the commercial market in order to help new companies and incite experiments and innovation needed to push game development on to 'the next level'. This can not be done by the industry or by venture capital alone.

There is a need for a coordinated political strategy that includes research, education, funding, venture capital and new business models to create such a 'hot spot' for future game development. Alain Tascan, CEO at Electronic Arts, has pointed to Scandinavia as a possible future 'hot spot' in his "hot spot forecast" presented at the Game Developers Conference Europe in London (September $1^{\text {st }} 2005$ ). Tascan put forward a list of conditions which must be met in order for a 'hot spot' to develop, ranging from "relevant institutions of education", "a high degree of IT infrastructure", "a high degree of regional cultural activity (production of music, movies/TV, sports, fashion, design)" to a "proactive support by governments and local authorities" (Moos 2005'). Looking at the Nordic countries as a whole and the Scandinavian countries in particular most of these conditions are fulfilled: Computer game research in the region has grown to become highly acknowledged on a global scale, computer game studies are emerging in both Norway and Sweden and especially in Denmark which has got a national game academy as a joint-venture between the universities, art schools and the game industry (http:// www.dadiu.dk). And the Nordic countries are well-known for their cultural traditions especially when it comes to producing cultural products for children and young people. And over the last five years efforts have been made to develop a culture political strategy for computer games resulting in a lot of surveys (see list of references) that map the game industry and its conditions concluding (in different ways) that computer games no longer can be regarded as sub cultural artifacts, but have moved "from a niche stage to becoming a wide-ranging, culture-carrying phenomenon" which require "viewing them in a way that is similar to the other cultural spheres - in line with literature, music, theatre, film, and so on. This raises a number of questions within cultural politics - mainly regarding talent, creative competences and content development methods" (Fonnesbch 2002: 5). And I might add: Regarding how to evaluate the quality of new game concepts 
and products, that is developing an analytical apparatus for judging computer games rooted in a profound understanding of the specific characteristics of computer games. This may make way for a political strategy aiming at "a more diverse and quality-oriented range of games in [...] the Nordic countries as an alternative to the global marked" (Kulturministeriet 2005) and aiming at encouraging production of new games by means of funding "development and production of interactive fiction for both children and adults" (Kulturministeriet 2001: 6) or by means of establishing contact between the game industry and "the rest of the media industry, venture capital and the educational system" (Mediesekretariatet/Det Danske Filminstitut 2005: 25):

To achieve a richer, high-quality offering of Nordic computer games for children and youth, there is a need for improved information, both market data and consumer information. A better infrastructure is required, with improved distribution and better conditions for the producers to be paid for their efforts. A supply of labor with the appropriate skills is necessary. Improved financing with a selection of different forms for support and investment capital is also needed. (Robertson 2004: 6)

As prosperous as this may seem there is still a lot to be done before the region may evolve into a new 'hot spot' for computer game development. Venture companies tend to support well-established companies such as IO Interactive (Hitman-series) and Funcom (Anarchy Online) while being reluctant when it comes to investing in new companies (and new game concepts). And the possibilities for public funding both on a national and regional scale are rather limited compared to existing 'hot spots' such as Canada, England and Korea: In England research and development costs are refunded $150 \%$ by the state, which is public funding on much larger scale than the 11,5 million USD budget for game development support established by the Nordic Council for the period 2006-2012, and furthermore the English funding system aims directly at game production and not at improving export possibilities, distribution and versioning systems to make it easier to translate games into local languages as is the case with the Nordic fund: This implies that the Nordic support system will benefit the established game industry more than new companies "struggling to get their first production financed" (Moos 2005). Still it would be premature to be too critical: Efforts are being made, and both in the field of research and education and in the field of venture capital things are moving in the right direction. However, the main problem is the not yet fulfilled need for an analytical apparatus and an understanding of computer games characteristics which can create a basis for the development of a proactive culture political strategy on a larger scale.

\title{
The Major Obstacles: Prejudiced Debate on Dangerous Content and Computer Games' Possible Damaging Effects
}

Even the most unrestrained, violent fiction is at its worst harmless because it takes place within something any normal person recognizes as pure fantasy, and at its best useful because it may produce a kind of catharsis which cleanses our system of our aggressions.

\author{
Eric Bentley: The Life of the Drama (1964)
}

Even though computer games have grown to be one of the largest fields within the socalled culture and experience economy, computer games are often regarded with 
skepticism and debates on computer games often seem to evolve around questions about whether computer games have possible damaging effects on their users. This debate led by politicians as well as parent organizations, religious organizations and so on and fueled by news media being eager to reproduce dubious scientific and psychological studies claiming that computer games create violent behavior and are as addictive as narcotics - often depicts computer games as trashy entertainment which is of no value at best and which may have damaging effects on its users at worst. This debate reproduces a hierarchy of values which is inherent in the traditional differentiation between art and popular culture which is expressed through "a series of dichotomies: authenticity/plagiarism, originality/copy, innovation/tradition [...]" and which imperceptibly leads to a "social and psychological hierarchy of effects" (Drottner 1999:53).

The field of culture and media politics is still characterized by debates on whether computer games create addiction and antisocial behavior. In this respect the culture political debate in the Nordic countries bares striking similarities to the media skeptical - and often morally biased - campaigns against computer games which contains elements of sex and violence that have been executed especially in USA and Australia. Here games like Grand Theft Auto, Narc, and 50 Cent: Bulletproof have been banned. In the US the states of Florida and California (the latter ironically governed by Arnold Schwarzenegger, former actor in highly violent movies like Terminator and Conan - the Barbarian) have introduced non-violence acts against computer games and New York governor Hillary Clinton is working on a nation-wide prohibition against games containing sex and violence. And using very superficial 'methods' of evaluation strong organizations like the parent organization Family Media Group have put up warnings against "the ten most violent games in the world" (Oftebro 2005b).

If we search the archives containing debates on computer games in the Swedish and Norwegian parliaments over the last few years we find that these debates mainly focus on possible initiatives to protect children and young people against the possible damaging content of computer games. Even though such a debate in some ways is quite legitimate (studying children's use of media and the media's effect on them is an important field of research) and has led to a rating system for computer games which e.g. indicates which age group a certain computer game targets (and which e.g. indicates that highly criticized computer game like the Grand Theft Auto-series is not meant to be played by children), this debate is in danger of resulting in political strategies which will appear both restrictive and reactionary and thus will fail to support the development of new and qualitatively better content for interactive culture products. On the contrary it will just state that there are some types of content which are reprehensible no matter how these types of content are designed and displayed.

In this line of argument some of the culture political efforts made concerning computer games appear as a return to earlier days' politics of restriction and censorship. Thus the computer game Grand Theft Auto 3 got reported to the police by the Norwegian children's ombudsman due to its violent content, and in the following debate in the Norwegian parliament it was suggested to treat the game along the same lines as child pornography (http://www.stortinget/no/cgi-wift/wiftldles?doc/usr/-www/stortinget/stid/ 2002/s021218-01.html). And even though the public prosecutor found that the game's degree of violence did not exceed that of many action movies and refused to press charges, the minister of children and family affairs decided to make the game object to censorship. 
This kind of politics of restriction and censorship can be found even in established systems for support like e.g. the Norwegian system for funding development of new media which has been limited to funding only "non-violent computer games" (Kultur og Kirkedepartementet 2003). And in Sweden a similar restriction can be found in the establishing of the semi-public organization Fair-Play which aim it is to encourage production of "clean games", that is computer games without explicit violent content (http://www.fair-play.se). The problem here is that culture political strategies are determined by prejudice and incorrect information (e.g. that computer games are played by deranged boys who then go off and massacre their fellow high school students) and a misconception of what computer games really are and - even more important - how they are perceived.

Danish media researcher Carsten Jessen (2000) points to the fact that it is an illusion to believe that violent computer games exclusively are played by lonely boys in dark basements, which is also one of the conclusions made by the Norwegian survey A digital childhood? (Endestad et.al. 2004). The survey states that it does not seem to be the fact that children who got access to new media and spend a lot of time using them are spending less time on activities like sport, outdoor play and visiting friends. Children's use of computer games is far more complex than usually anticipated and computer games thus play an extensive social role, as Carsten Jessen demonstrates in a survey of young boys' use of action games, in which he states that playing games covers a variety of different activities all of which may evolve around the game even though playing the game itself is just one activity while others concerns competition, exploration, exchanging of knowledge and so on (Jessen 2000: 120-121). Thus the game experience - "playing the game" - contains much more than just the player's interaction with the game universe, and in this light, Jessen regards computer games as "good tools for creating spheres in which social fellowship and play may emerge" (Jessen 2000: 121). As Danish drama teacher Klaus Thestrup explains, computer games are par of a larger media circuit: "Computer games encourage different types of play which again may encourage creative production or storytelling", which is why it is useful when evaluating computer games and their impact on children and young people to regard them as "just a small part of a greater whole, and if we want to understand their importance, we need to consider the whole situation" (Thorhauge 2005: 110).

To differentiate the debate on computer game's damaging potential it may be added that very few studies have been able to show any connection between the use of violent computer games and violent behavior, as concluded by a widely composed panel of experts assigned by the Danish Ministry of Culture to summarize the international research results concerning media and violence. The survey concludes:

As a whole the studies on which this survey is based do not bare any evidence that could indicate that representation of violence in moving pictures in itself should result in violent behavior in normally functioning children and young people. When children and young people commit acts of violence this must be seen a result of the interplay between many different social circumstances in which the experience of violence in moving picture may be a contributing factor (Kulturministeriet 1995: 59).

The fact that playing violent computer games does not cause any damage or provoke violent behavior connects to the fact that "when it comes to violent play, children are usually better than adults at differentiating play from reality" (Egenfledt-Nielsen and 
Smith 2000: 120). We may point out that "adults often underestimate children's and young people's ability to see the difference between reality and fiction" (ibid.). One of the characteristics of children's play is that it trains the child's ability "to read fiction" (Krøgholt 2001: 186), that is to acknowledge fiction as separated from daily-life activities: It's just something we are playing. And this ability to separate between fiction and reality is also at work when we engage in other types of fiction in which the amount of violence can be equally large. When the debate in the Norwegian parliament quoted above equals consuming child pornography and engaging in fictional acts of violence in Grand Theft Auto 3 this is an example of politicians not being able to maintain an equal differentiation. Here levels are blended and boundaries blurred: Pornography is not fiction and demands sexual exploitation of e.g. children while Grand Theft Auto is 100 per cent fiction: The action is played out by and by using absolute fictional game characters: No-one suffers for real.

Off course, when looking superficially at computer games from 'the outside', the amount of violence might be offensive. There is a lot of violence taking place in computer games; a lot of slaughtering various enemies or innocent bystanders (or both), a lot of blunt and murderous attacks, a lot of silent assassination, a lot of fighting and mutilation - and obviously it's a lot of fun! The novelty of computer games though does not lie in the presence of often extreme violence, but in the fact that we can partake in the killings and beatings in a more tactile and interactive way than in other forms of fictional violence. We have always been fascinated by violence, and violence as aesthetic and dramatic effect has been an important ingredient literature, theatre, movies since the dawn of our culture. The amount of murders, rapes and immoral behavior in computer games does not exceed that of Greek tragedies, the baroque farce, the average action or horror movie or Tom \& Jerry cartoon. Actually some of the most horrifying dramatic scenarios are yet to find their way into the computer game - even when it comes to games which evolve around immoral actions such as drive-by-shootings and killing off innocent bystanders or killing off opponents in sophisticated ways: Killing your own children - as Medea does in Sophocles' tragedy - or the butchering of your enemies' children and serving them as pie to their mother as in Shakespeare's Titus Andronicus is yet to be seen in an interactive version. The widely criticized 'secret sexscenes' in Grand Theft Auto - San Andreas appear rather innocent and childish compared to the 'sleeping with your mother after having killed your father'-scenario of Oedipus Rex.

My point is that apart from the fact that in computer games we partake in violent action not only on the level of perception but also in a tactile way - that we don't just read about e.g. king Theseus going into to labyrinth of Crete to kill the Minotaurus, but that we in a game like Doom use our mouse and keyboard to go monster hunting in the labyrinth ourselves - apart from that: When it comes to studying what's so fascinating about violence in computer games, it is plausible to ask: What is so fascinating about fictional violence, violence in an aesthetical format as such? This means that when looking at how the use of violence functions in different types of computer games we can look at how violence functions in other works of fiction, e.g. in different dramatic genres.

In his book The Life of the Drama (1964) theatre theorist Eric Bentley deals with the use of violence in farce, melodrama, comedy and tragedy. His point is that violence as dramatic effect functions in different ways depending on the genre and depending on to what degree we identify our selves with the characters and the dramatic story. Do we feel sympathy for the protagonist or not, do we fear the antagonist or not - and so on. 
I will give you one example: One of the dramatic genres containing a high degree of violence and a lot of aggression is the farce (Bentley 1964: 264ff.). Here we do not sympathize much with the protagonist, but more important: we certainly do no fear the antagonist (or antagonists, there are often quite a few). Here contempt for the enemy is crucial and the aggression this contempt produces is what creates the dramatic action. Its not possible - and certainly not useful - to feel any compassion with the victims of our (that is the protagonist with whom we identify) aggression, because there is too much fun and pleasure in sacrificing them. You do not run away, you attack. It's a very physical form with little room for arguments and reasoning. You hit and you hit hard. No questions asked. And the execution of brutal violence with no consequence is the main characteristic. The farce challenges moral, ethics and any other system of law and order. It's a safe haven from normality, moderation and safe-play of any kind. The farce is not only absurd, it presents a structure of absurdity, a universal and manic and most of all violent racing around which produces aesthetical satisfaction.

A lot of computer games resemble this dramatic genre. Various kinds of shoot'em ups with Doom and Quake series as some kind of archetypes can be seen as farces. Attacking is the major mode of action. It's all about beating and shooting our way through a series of levels on which new enemies appear replacing the ones we already have had the pleasure of killing. You fight your way through the labyrinth blasting monsters with a wide range of lethal weapons at your disposal. Any compassion for these monsters is off course out of the question. And there is not much sympathy for the protagonist (that is the game character you are operating) either. The game character in games like Doom and Quake is reduced to mere functionality, to a set of skills and weapons: "Here, the "character" is better considered as a suite of characteristics or equipment utilized and embodied by the controlling player. The primary-player-character relationship is one of vehicular embodiment" (Newmann 2002). In fact your character is not much more than the barrel of a gun pointing into the screen and a display informing you about how much ammunition you've got left, the score, health situation, lives left on your account and so on: All important vehicles for the violent tour de force which is what makes these games so fascinating.

So, violence in computer games can be characterized as exaggerated in the same way as the farce, the comic book and the action movie in which violent and spectacular effects are part of the genre's aesthetics. As Danish media researcher Anne Jerslev (1999) points out, the use of violence (in movies) is usually based on some kind of aesthetical idea and she differentiates between 'cartoon violence', 'splatter violence', and 'realistic violence', and the point is that only the latter is to be taken serious, while use of blood, gore and extreme violence in e.g. the 'splatter' movie or game works as some kind of "humoristic, ironic comment, which the genre initiates" (Sørensen and Jessen 1999: 15).

Instead of making superficial and prejudiced evaluations of violence in computer games what we should do is to ask: Which role does the violence play? It is beyond any discussion that Stanley Kubric's A Klockwork Orange, Francis Ford Coppola's Apocalypse Now and the Die Hard-series all are highly violent movies. But at the same time it is also undisputable that the violence plays quite different roles in these movies. In the former two, violence is used respectively as society critique and warfare critique, whereas in the Die Hard-series the use of violence is embedded in an action movie tradition as well in the ironically aesthetics of violence of the 1990ties in which violence function as pure spectacular effect with an ironical twist. The violence in Grand Theft 
Auto has the same characteristics as that of the Die Hard movies: We are in "Pulp Fiction-land where form comes before content and humor rarely can be suppressed by the brutal effects" (Smith 2003) and where the outrageous actions are placed in ironical brackets. Here violence is to be regarded as unreal and non-realistic: "It's just so exaggerated!" as one of the children interviewed in Holm Sørensen and Jessen's survey explains (1999: 35). But the main point here is that use of media containing violence (as well as use of media containing all other sorts of things) always is enclosed in a context in which the media is being used for different purposes like for instance a basis for personal reflections, creativity and, in the case of children, as a starting point for larger play communities and further play. When we wish to study how children and young people experience, reacts to and perceives computer games (whether we do that to survey their effect or to judge quality in a computer game) we have to look into the context of the game experience as well as the specific mode of reception at work in computer games:

The fact that children playing computer games are co-producers who control, act and choose have an impact on their fascination by computer games and on the games' potential effects. Thus immersion in the fictional universe of computer games is of another type than immersion in movies and novels. While the absorption when reading novels or watching movies is about getting carried away or daydreaming, computer games demand that you are acting actively. (Holm Sørensen and Jessen 1999: 14)

\section{Evaluating Quality in Computer Games: Understanding the Media}

So what I have tried to outline so far is a situation where computer games often are subject to prejudice and misconception resulting in culture political efforts which engage in restrictions and censorship. This situation calls for a set of concepts and an analytical apparatus that can make a starting point for evaluation of quality in computer games and thus an progressive culture political strategy targeting innovation and experimentation as important issues: What is a computer game, how do various computer game genres function, how do different age groups use computer game? And how do we secure a higher quality in the new media and the new use of media? The key concept is off course 'quality'.

Quality is a concept often used in culture political debates. The problem, however, is that the concept usually is being used in an unreflective and undefined way which enables crude differentiation as when politicians refuse to "label computer games as culture but labels them as entertainment, which must manage on their own": Computer games are "obviously a commodity" that should not be included by a public culture political strategy (Hebsgaard 2004b). Here a vague and undefined use of the concept results in a differentiation between culture (that is worth funding) and commercial entertainment. Actually it is rather hard to find any clear-cut definition of 'quality' as it is being used in the culture political debate, even though the concept obviously has a great importance. The reason why I am making a point out of this is that it seems imperative to have some over-all thoughts on the very nature of 'cultural quality' in order to formulate a progressive culture political strategy. What is the meaning of the concept 'quality' when the Nordic Council decides to spend 11,5 million USD on "developing Nordic quality games" (Oftebro 2005a)? As I have indicated quality to some extent seems 
to imply a certain type of content, which is first and foremost characterized by its nonviolent character, and which more vaguely bare references to a certain Nordic "storytelling tradition within literature and movies and promotion of art and culture of high quality" (Mediesekretariatet/Det Danske Filminstitut 2005: 25).

I do not want to engage in a definition of quality as such, but want to focus on presenting a concrete quality concept which may be used not only to judge the content of a cultural product, but also to zoom in on communicational, craftsmanlike and socializing aspects. This concept of quality has been developed by Danish cultural scientists Karen Hannah, Charlotte Rørdam and Jørn Langsted, presented in their book The IANmodel. A handbook on evaluating Theatre, Dance, and Music (2005). Their model for evaluation of performance art will produce a useful starting point for my description of the uniqueness and special characteristics of computer games. Being a model developed for performance art makes it all the more useful because the characteristics of a performance, that is the artistic expression unfolding within a time-space continuum shared with its audience, resembles the real-time reception in computer games, that is the game unfolding as a result of the player's interaction with the game. The IAN-model displays three parameters in which quality can be evaluated. Quality is regarded as interplay between a cultural product's Intention, Ability and Necessity.

Intention is defined as consisting of "a will to express and communicate":

The will to expression comes from within and is turned outwards. The artist shapes his or her visions, ideas and experiences of the world, of life, of human fellowship, and in this process of shaping thoughts and experiences and willingness to express oneself, ambitions, self-conceit and energy of expression are also at work. And this is so because an art work is not just a description of an outside world - it is a choice between all the world's many elements combined with some kind of intention. Through art the world is processed. (Hannah et.al. 2005b)

In game design intention is connected to the developing of a game world and structure of possible actions and events inherent in this world. Computer games present themselves as fictional worlds which the player is invited to take part in as a major agent in the interactive plot structure. The fiction (and I use the word fiction to avoid the more biased word 'narrative') found in computer games presents itself as interactive and - to use a term coined by American computer game theorist Celia Pearce (2002) - as playcentric. It is interactive in that it is constituted by interactions between a fictitious world and a plot structure (how ever complex and multi-threaded) and a player's action within and in relation to this world and structure. It is play-centric in that this interaction between game and player uses role-play as its primary mode. Here computer games differs from other types of fictions which are fixed entities and present them selves as 'told' - even when they unfold in real-time in front of its audience like in the theatre (Cf. Bordwell 1985).

Computer game fictions come in many shapes and forms - 1st person shooters (Counter-Strike), adventure games (Myst-series), strategy games (Civilization), sports games (from the almost abstract table tennis match found in Pong to the complex soccer-scenarios of the Fifa-series), war games (Battlefield 1942), combat games (Tekkenseries), and vast fictional online-worlds, which work as arenas for improvisation with player-designed characters (Ultima Online), but their differences aside they all have one thing in common: role-play and participation in some kind of story-producing process 
or "production of [...] events" (Klastrup 2001). They may be described as spatial structures (Manovich 2002) or as emergent structures, i.e. fictions with a plot-line evolving and developing only due to the player's actions (Jenkins 2001). Or they may be regarded as dramatic narratives with the player as main character. This is the case whether the player engages in playing the part of the space soldier in Halo, the assassin in Hitman, the adventuring heroine in Tomb Raider or she puts on the role as creator of systems; families, cities, empires in The Sims, SimCity or Civilization. And in a massively multiplayer online role-playing game (MMORPG) like e.g. Ultima Online this roleplaying mode has been extended to the degree that the player can create her own unique character using the creative tools the game has to offer and by using this character she can create her own story-lines together with other player-characters and non-player characters (NPCs) within the framework of the game's fictional world.

Thus interactive and play-centric dramatic fictions imply a transformation of the recipient. From merely playing the role as a spectator to the dramatic story unfolding in front of her, she is offered a role within the fiction itself. Thus the interactive and playcentric fiction found in computer games dissolves the line between spectator and fiction, which is why it is not to correct, as claimed by Brenda Laurel (1991), that interactive systems (regarded "as theatre") imply that the audience enters the stage and becomes actors. It makes little sense to talk about actors and audience in the traditional sense. There is no point outside the game from which an audience is intended to watch and therefore there is no-one for an actor to act to. A game is not meant to be watched like a theatre performance. The central issue in a game is to play. This involves different demands on the interactive and play-centric fiction than on traditional fictions, which are meant to be read or watched. Narrative contingency, psychological character development, depth in characters as well as story plays to some extent a minor role compared to possibilities for the recipient to play a role within the story. The point is not to discover, reveal and to read for the plot (Cf. Brooks 1984), but to play the plot. To evaluate the intension of a certain computer game design is to examine the quality of this special type of fictional universes and its interactive plot-structure and the game experience this produces.

The ability-parameter of the IAN-model is explained as follows

The artistic ability comprises specific skills that vary from one artistic field to another. These skills are trained and sharpened, partly through artistic schooling, a kind of apprenticeship, an partly through years of practice and experience. Artistic ability is a prerequisite for expressing and communicating, and the demands made on artistic ability are often highly specialized. Success is dependent upon mastering the artistic forms of expression and this applies to the arts in general. (Hannah et.al. 2205b)

In game design this parameter addresses the designers' ability to create convincing and well-functioning graphical worlds and animated characters that can move around and interact with each other and with these worlds all embedded in an interactive structure which the player can influence. This structure of game universe and possible player actions is what we usually term a game's gameplay. Game designer Richard Rouse (2001) defines gameplay as the one component in computer games, which can be found in no other art forms; that is interactivity: "A game's gameplay is the degree and nature of the interactivity that the game includes, i.e. how the player is able to interact with the game-world and how that game-world reacts to the choices the player makes" (Rouse 
2001, p.xviii). In the context of this article, however, I will claim that gameplay cannot solely be linked to the game's interactivity; gameplay is also connected to the game's fiction. Computer games may be described as both a system of rules and as fiction in that "playing a [computer game] is to be engaged in the interaction with some real rules while imagining a fictional world" (Juul 2005: 2). However, rules are not only found in games and play-centric fictions. Even classic, closed and static non-interactive fictions set up rules for the reader or spectator concerning their conduct and how the fiction should be perceived. Umberto Eco (1979) labels the strategic rules governing the reading of a text Model Reader, which is not a particular real-life reader, but a set of readercompetences that the text anticipates and the reader must meet these anticipations in order to produce the best reading. In theatre performance such rules of reception are usually summed up in the concept contract of fiction, which determines the communication taking place between performance and spectator and includes a basic framework for understanding what is going on, for instance that what is taking place on stage is fiction and not reality, what genre this particular fiction belongs to and so on.

In computer games, however, this contract of fiction is not limited to regulating the possible interpretations made by the spectator, but includes rules governing how the player may interact with the game and its fiction and is as such imperative in order to make it possible for the player to play the game at all. The player must understand the gameplay in order to get a satisfactory game experience. And when looking at the game's fiction and how it may be 'read', it is important to be aware of these rules because they are an implemented part of this 'reading'. When we analyze a game's interactive fiction we analyze a dynamic structure that evolves as we analyze and interpret it. We analyze our own actions according to the rules of the game and to our positions as players in the game universe and according to the game characters we operate as well as we analyze the story (or stories) emerging from our actions. And what makes this analysis all the more complex is that our interpretations constantly and recursively reenter the game itself as new starting points for further gameplay action and development. So when it comes to evaluating quality in computer games the ability of game designers is all about how good and challenging the interaction design embedded in the concrete computer game is: A game of high quality produces possibilities for interesting and challenging interactions and interplay between game and player.

Finally the IAN-model defines necessity as:

the relation to the audience, to the surroundings, to the society in which the work of art is performed. [...] This implies that a good work of art must consist of some kind of necessity which reaches beyond the artistic intention and ability. The art work - the artistic initiative - must evoke a response in a reality populated with smaller or larger groups of people, characterized by specific social and psychological traits. The work of art must be characterized by acting upon these people and their social and psychological situation in a way with appears revelational, believable and imparts a sense of immediacy. (Hannah et.al. 2005b)

When evaluating computer games, necessity will connect to the user-dimension, meaning the way in which the game approaches its player (user) and the way in which the game initiates different gameplay situations and different types of player communities. This off course is dependent on both game genre, game format and game platform. The social dimension of e.g. MMORPGs is constituted partly by working together within the fiction framework and partly by players who outside the fiction discuss the possibilities 
for changes and new story-lines inside the game's fiction and who exchange experiences and stories on the multitude of websites surrounding the game or by using the game's chat channel. This kind of social player activity both in character and out of character is an important part of what makes the game fascinating and is encouraged by the game designers in the sense that great missions in the upper experience levels of the game necessitates that players make their characters join forces in clans and guilds. As Lisbeth Klastrup points out, "the characteristics of a given world may be defined respectively in the cross between aesthetics and structure (the world's appearance, its design as fiction universe and game system) and the social dimension (the social text emerging from the encountering of the users of the world centered on the use of it)" (Klastrup 2004:.239).

Necessity is a parameter for the designers' ability to structure the game's rules and fictional world in ways that engages the player and ways in which the player can make the game connect to a larger cultural and social context e.g. as a means for social interactions. Here the computer game may become part of different types of communities and also come to play an important role in the way players handle the modern world as such and in which media play a dominating role as something in relation to which modern people understand themselves (and by which they mirrors, mediates and stages themselves). Here computer games are an important part of the media picture alongside reality-tv, sit-coms, docu-soaps and so on: "Due to the absence of coherent dramatic narratives in connection to which we can understand our lives there is all the more need for drafts from which ideas can be drawn, and media is off course obvious reservoirs for doing so" (Jerselv 2002). As such computer games may be used as media matrices which present themselves as tools for developing identity and understanding of self in modern human beings as well as tools for coping with the complexity of the world. Thus the utility of media matrices is on the one hand expressed by being "simple and recognizable" and on the other "leaving room for the users to add aspects, associations and accents which evoke personal response and meaning" (Drottner 2002: 36-37).

At the same time media play a crucial role to the way in which modern human beings get information and communicate with each other: Modern, digital communication is due to its interactivity to high degree based on computer game formats and this is why playing computer games may be regarded as means to train general media competences as well as other competences needed in today's hyper-complex society in which analyzing and acting according to complex structures of meaning is vital and in which the "ability to adapt, the ability to be part of mobile teams, to believe in oneself, the ability to communicate a strategy and to understand information" (Pedersen 2003), which are what characterize e.g. the players of online multiplayer games like CounterStrike, are qualities demanded e.g. by the business community.

Thus computer games function as media training and rehearsals in handling complexity whether this takes place in the shape of violent play (when playing an action game like Grand Theft Auto) or in the shape of mastering complex structures of meaning (when solving complicated puzzles in an adventure game like Myst or when building large systems in a strategy game like Civilization) or in the shape of experimentation on social structures (when playing the build-your-own-family game The Sims). To examine to what degree computer games enables these kinds of social learning processes would be one way of examining the quality of computer games' necessity. 


\section{Conclusion}

An evaluation of quality in computer games may - as I have argued - take its beginning in an understanding of computer games as new structures of fiction, which uses interactivity as its distinctive mode of reception (which is why computer games in a profound way differ from other types of fiction). Using a concept of quality which enables an evaluation of computer games using intention, ability, and necessity as parameters it is possible to evaluate concrete computer games' fictional universes and interactive structures of actions and events and the game experience these produces. It is possible to examine and pass judgments on the possibilities for interesting and challenging interactions and interplay between game and player utilized by the game design. And it becomes equally possible to examine how the computer game meets its player and the way the game may initiate different modes of use, different situation the game may be played in, and thus how the game creates a sphere for different kinds of communities. My concluding remark is that this model for evaluation of quality in computer games may be used as a starting point for formulating a culture political strategy concerning computer games in which computer games are not merely exposed to superficial (and judgmental) ratings and subject to political initiatives which mostly expresses reactionary regulations, restrictions and censorship. On the contrary the model may initiate a political strategy for evaluating computer games on their own premises in the same way as e.g. movies are being evaluated. Using the suggested concept of quality and analytical apparatus a progressive cultural politics may be formulated which can support computer games development indirectly by making better channels for distribution and by joining forces with venture capital and directly by supporting development of competences as well as development of products and which objective will be to initiate and support the development of a Nordic 'hot spot', that is a setting for Nordic game development focusing on designing innovative and challenging computer games.

\section{Note}

1. All foreign quotations are translated into English by the author.

\section{References}

Bentley, E. (1964) The Life of the Drama. New York: Applause Theatre Books.

Bordwell, D. (1985) Narration in the Fiction Film. London: Routledge.

Brooks, P. (1984) Reading for the Plot. Cambridge MA: Harvard University Press.

Børne Index/Gallup (2002) Børn, unge \& computerspil [Children, young people \& computer games]. Copenhagen: The Media Council for Children and Youth.

Drotner, K. (1999) Unge, medier og modernitet [Young people, media and modernity]. Copenhagen: Borgen.

Drotner, K. (2002) 'Når virkeligheden overgår fiktionen: mediematricer mellem det kendte og det ukendte' [When reality exceeds fiction: media matrices between the known and the unknown], in Qvortrup, L. (ed.) Mediernes 11.september [The media 9-11]. Copenhagen: Gads Forlag.

Eco, U. (1979) The Role of the Reader. Explorations in the Semiotics of Texts. London: Hutchinson.

Eco, U. (1989) The Open Work. Cambridge MA: Harvard University Press.

Egenfeldt-Nielsen, S. and Smith, J. Heide (2000) Den digitale leg [Digital play]. Copenhagen: Hans Reitzels Forlag.

Egenfeldt-Nielsen, S. and Smith, J. Heide (2003) Computerspil og skadelighed - en forskningsoversigt [Computer games and harmfulness - a research survey]. Copenhagen: The Media Council for Children and Youth.

Endestad, T. et.al. (2004) En digital barndom. En spфrreundes $\phi$ kelse om barns bruk av medieteknologi [A digital childhood. A survey on childrens use of media technology]. Oslo: Norwegian Institute for Studies on Childhood, Welfare and Aging. 
Fonnesbech, C. (2002) The Interactive Culture Industry. Copenhagen: The Danish Ministry of Culture/ KPMG Consulting.

Gynther, K. (red.) (2003) Bфrn, unge og computerspil [Children, young people and computer games]. Copenhagen: The Media Council for Children and Youth.

Hannah, K. et.al. (2005a) Ønskekvisten. En håndbog i evaluering af Teater, Dans og Musik [The IANmodel. A handbook on evaluating Theatre, Dance, and Music]. Aarhus: Forlaget Klim.

Hannah, K. et.al. (2005b) 'Evaluation of quality in the performing arts'. [http://www.aestetik.au.dk/ oenskekvisten/eng/present].

Hebsgaard, S. (2004) 'Skal computerspil have kulturstøtte?' [Should computer games be culturally funded?]. Copenhagn: Berlingske Tidende December $30^{\text {th }}$.

Jenkins, H. (2001) 'Game Design as Narrative Architecture'. [http://web.mit.edu/21fms/www/faculty/ henry3/games\&narrative.html].

Jerslev, A. (1999) Det er bare film. Unges videofallesskaber og vold på film [It's just a movie. Young people's video communities and violence on film]. Copenhagen: Gyldendal.

Jerslev, A. (2002) 'Det intime' [The intimate]. Copenhagen: Dagbladet Information January $11^{\text {th }}$.

Jessen, C. (2000) 'Når drenge spiller actionspil' [When boys play action games], in Holm Sørensen, B. and Olesen B.R. (eds.) B $\phi r n$ i en digital kultur. Forskningsperspektiver [Children in a digital culture. Research perspectives]. Copenhagen: GADs forlag, p.109-123 .

Juul, J. (2005) Half-Real. Video Games Between Real Rules and Fictional Worlds. Cambridge MA: MIT Press.

Klastrup, L. (2001) 'Adventures in StoryMOO - online textuality in play'. [http://www.it-c.dk/people/ klastrup/-atricles.html].

Klastrup, L. (2004) 'EverQuest som en ny tids fiktion. Kommunikation og interaktion i en online spilverden' [EverQuest as a fiction of new times. Communication and interaction in an online game world], in Engholm, I. and Klastrup, L. (eds.) Digitale Verdener [Digital Worlds]. Copehagen: Gyldendal. p. 235-254..

Krøgholt, I. (2001) Performanceteater og dramapadagogik - et krydsfelt [Performance theatre and drama in education - a cross field]. Aarhus: Aktuelle Teaterproblemer 47, Dept. of Dramaturgy, University of Aarhus.

Kultur- og Kirkeministeriet (2003) 'Satsing på norsk filmproduksjon' [Efforts for Norwegian film production]. Newspaper announcement. Oslo: The Norwegian Ministry of Culture and Church Affairs [http://odin.dep.no/kkd/norsk/aktuel/pressesenter/pressem/0403031-070149/doku-bu.html].

Kulturministeriet (1995) Medievold, børn og unge. Rapport vedr. film, tv-og videovold [Media violence, children and young people. Report concerning movies, tv, and video violence]. Copenhagen: The Danish Ministry of Culture.

Kulturministeriet (2001) Kunst i netvarkssamfundet [Art in the network society]. Copenhagen: The Danish Ministry of Culture.

Kulturministeriet (2005) 'Danske computerspil har stort potentiale' [Danish computer games have great potential]. Newspaper announcement September $8^{\text {th }}$ [http://www.kulturministeriet.dk/sw27740.asp].

Kulturministeriet og IT- og Forskningsministeriet (2001) Konvergens i netvarkssamfundet [Convergence in the network society]. Copenhagen: The Danish Ministry of Culture and Ministry of IT and Science.

Manovich, L. (2002) The Language of New Media (revised edition). [http://www.manovich.net/].

Mediesekretariatet/Det Danske Filminstitut (2005) Computerspil i videns- og oplevelses $\phi$ konomien. Den danske spilbranches $\phi k$ onomiske og kreative vakstmuligheder [Computer games in the knowledge and experience economy. Danish game industry's economical and creative potential]. Copenhagen: The Danish Ministry of Culture/The Danish Film Institute.

Mikkelsen, B. (2002) 'Bedre interaktivt indhold' [Better interactive content]. [http://www.djh.dk/ejour/ 0902/-18BedreInteraktivtIndhold.html].

MMI as (2003) Rapport. Resultater fra SAFT-barneundersøgelsen [Report. Results of the SAFT-children's survey]. Copenhagen: The Media Council for Children and Youth.

Moos, H. (2005) 'Globale hot spots for spiludvikling: Status på Øresundsregionen' [Global hot spots: Status on the Øresund region]. Copenhagen: Newsletter for Diginet Øresund September $8^{\text {th }}$ [http:// www.diginet.org/o.o.i.s?id=1051\&news_item=229].

Newman, J. (2002) 'The Myth of the Ergodic Videogame. Some thoughts on player-character relationsships in videogames', in: Game Studies, vol.2 http://gamestudies.org/0102/newman/].

Oftebro, I. (2005a) 'Vil ha nordiske kvalitetsspill' [Wants nordic quality games]. IT-avisen. November $11^{\text {th }}$ [http://www.itavisen.no/art/1307601.html].

Oftebro, I. (2005b) 'Ekstremvold, horer og korruption' [Extreme violence, whores, and corruption]. IT-avisen December $1^{\text {st }}[$ http://www.itavisen.no/php/print.php?id=282145]. 
Pearce, C. (2002) 'Towards a Game Theory of Game'. [http://www.cpandfriends.com/writing/firstperson.html].

Pedersen, I. Kjøgx (2003). 'Op på næste level' [Advancing to the next level]. Copenhagen: Weekendavisen October 3-9.

Roberson, E. (2004) Nordiska datorspel [Nordic computer games]. Stockholm: Nordic Council/Redikod AB [http://www.norden.org/kultur/barn/sk/datorspel.pdf].

Rouse, R. (2001) Game Design. Theory \& Practice. Plano, Texas: Wordward Publishing Inc.

Smith, J. Heide (2003) 'Computerspillet på vej mod nye horisonter' [The computer game towards new horizons]. Copenhagen: Politiken October $8^{\text {th }}$

Sørensen, B. Holm and Jessen, C. (1999) Det er bare noget, der er lavet... [It's just something that has been made...]. Copenhagen: The Media Council for Children and Youth.

Thorhauge, A. M. (2005) 'Spil for børn og unge' [Games for children and young people], in Computerspil $i$ videns- og oplevelsesфkonomien. Den danske spilbranches $\phi$ konomiske og kreative vakstmuligheder. Copenhagen: The Danish Ministry of Culture/The Danish Film Institute. 